University of Louisville

ThinkIR: The University of Louisville's Institutional Repository

Electronic Theses and Dissertations

\title{
$5-2011$
}

\section{An exploration of the earthen feminine : the vessel.}

Sharon Madison 1955-

University of Louisville

Follow this and additional works at: https://ir.library.louisville.edu/etd

\section{Recommended Citation}

Madison, Sharon 1955-, "An exploration of the earthen feminine : the vessel." (2011). Electronic Theses and Dissertations. Paper 881.

https://doi.org/10.18297/etd/881

This Master's Thesis is brought to you for free and open access by ThinkIR: The University of Louisville's Institutional Repository. It has been accepted for inclusion in Electronic Theses and Dissertations by an authorized administrator of ThinkIR: The University of Louisville's Institutional Repository. This title appears here courtesy of the author, who has retained all other copyrights. For more information, please contact thinkir@louisville.edu. 
AN EXPLORATION OF THE EARTHEN FEMININE: THE VESSEL

By

Sharon Madison

B.A., University of Louisville, 1998

\author{
A Thesis \\ Submitted to the Faculty of the \\ College of Arts and Sciences of the University of Louisville \\ In Partial Fulfillment of the Requirements \\ For the Degree of
}

Master of Arts

Department of Fine Arts

University of Louisville

Louisville, Kentucky

May 2011 

AN EXPLORATION OF THE EARTHEN FEMININE: THE VESSEL

\title{
By
}

\author{
Sharon Madison \\ B.A., University of Louisville, 1998 \\ A Thesis Submitted for Approval on
}

April 1,2011

By the following Committee

\begin{tabular}{c}
\hline Principal Advisor \\
\hline Jon Begtey \\
Thomas Maloney
\end{tabular}




\section{DEDICATION}

For my daddy, Walter Madison, and my momma, Emma Jean Madison, who taught me to love learning and encouraged me to explore the earth.

For my sons, Jason and Jeffery Jackson, my reasons to live; and for my grandchildren:

Bradley Prahl, who shares my soul; Madison Jackson, who reminds me to have fun; Riley

Jackson, who shares wonderful stories about video games that I don't understand; and Ainsley Jackson, who shares what it means to be compassionate with us all. 


\section{Abstract \\ Sharon Madison \\ January 27, 2011}

Clay has been an integral part of my life from early childhood. The attempts of five-year-old hands to create vessels always ended up failures in my young eyes.

Having had the blessings in my life to study under Richard Burns and the Master, Tom Marsh, I have learned to create, in permanency, the kinds of vessels my five-yearold heart yearned for.

My exploration in the study of ceramics has been, and always will be, the center of my life in art. This exploration has brought me from the functional to an exaggeration of the functional. Away from the wheel, I have found a new comfort in the creation of my visions from my environment, my forest, my earth.

These works represent my vision of special places at the creek which runs far back in my woods. The texture and the visual pleasure of watching the effect of weather and time, on a spot of earth special to me, is the essence of my work. 


\section{TABLE OF CONTENTS}

PAGE

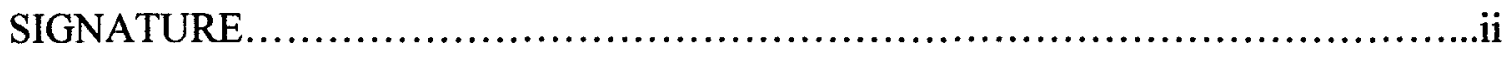

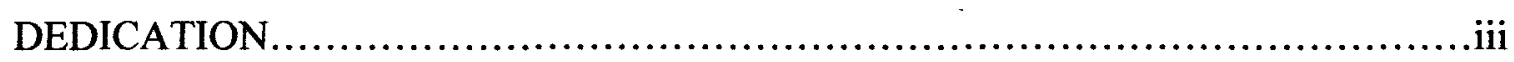

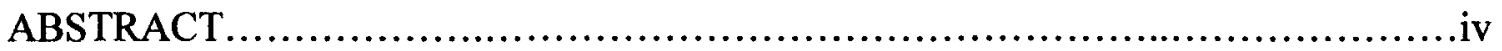

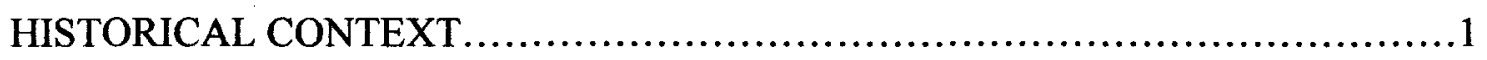

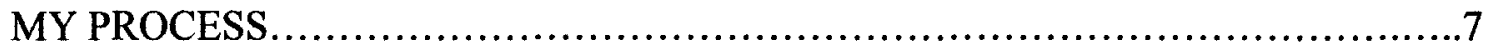

SUMMARY AND CONCLUSIONS..........................................

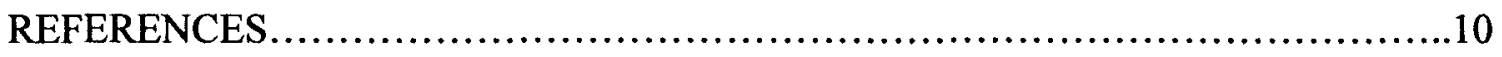

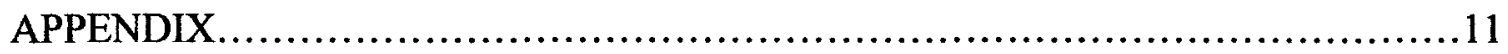

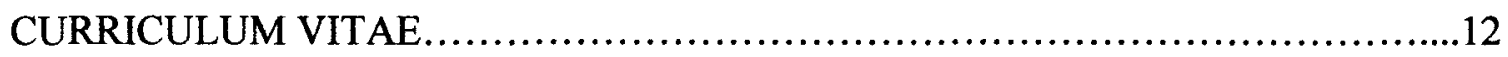


"Is there anything whereof it may be said, see, this is new!

It hath been already of old time, which was before us. There is no remembrance of former things;

Neither shall there be any remembrance of things that are to come with those that shall come after."

\author{
The Instruction of Ptah-Hotep and \\ The Instruction of Ke'Gemni, The \\ Oldest Books in the World \\ Anonymous
}

(Jacq, 2004)

\title{
HISTORICAL CONTEXT
}

Clay has been an important medium of expression throughout the history of humankind. The earliest pottery and other clay forms, such as tablets and stele, record the artistic values and aesthetic standards of the cultures for which they speak. Pottery has been created and used for a multitude of reasons, including communication, storage, and personal use. Stories inscribed in clay from cultures that had no writing systems have taught lessons of heroes and villains, lovers and enemies, war and peace to their contemporary societies as well as to modern readers, scholars, and students. Throughout history clay and clay products have served to honor gods and royalty as well as used by mankind for our most basic needs. We humans have, for millennia, created useful objects from clay that was dug by those same human hands. That connection to the earth 
is shared by many in the practice of functional pottery.

There is little argument that clay is an important medium in our everyday world of humans. The very omnipresence of functional pottery has driven clay artists to be concerned, not only with the technical aspects of form and function, but also with its purely aesthetic considerations of design. The ancient art of expression in clay has influenced the design of form and the decoration, applied or incised, of those forms generation after generation, and it is intrinsically important to further exploration into the art and craft of clay.

We create, today, in the same basic ways of our ancestors. We create bowls and drinking vessels, storage containers and cooking vessels, just like those from the past; but we speak from our own time. A bowl is, after all, a bowl. There is nothing new under the spectrum of sameness. But it is that variety of sameness over the history of ceramics that makes the craft so exciting and endless.

There is much information on the traditional techniques and aesthetic desirability of pottery produced by cultures globally. From the ancient tea ceremony vessels of the East, to the fine dinnerware that graced the tables of nobility in Europe and on to the sturdy functional wares of early Americans, clay artists have traditionally gravitated to the discipline that "fits" the individual craftsman.

From a technical and aesthetic view, finding that fit is crucial. The clay artist, by creating from a lump of earth, must be a part of the work to create the work. The hands are the most important tool in the plethora of mechanical tools. The hands wedge, center and throw clay. The hands form the vessel using tactile sensations. First, fingers feel the grog of a stoneware clay body or the velvet creaminess of porcelain. Pressure is applied and eased away as the form begins to leave the face of the potter's wheel. Then 
more focused pressure between the tips of the fingers, inside and outside of a wall, while pulling upward and assisting the form to emerge. This is where the artist must find the discipline which fascinates, influences and becomes a part of him.

The importance of tactility in crafting clay objects is observed by Philip Rawson in his book, Ceramics. Rawson notes that "...many of the other artifacts by which we are surrounded are made from materials, which by their surfaces, communicate virtually nothing to the sense of touch. Even our kitchens are lines with that ultimate in touch repellant surface, Formica" (Rawson, 1971). Objects created by thoughtful, empathetic hands beg to be touched. That desire to feel a surface texture and be satisfied with the visual/tactile sensations allow the observer to participate in the culminating test of an acceptable vessel.

Tactility is vitally important to the clay artist who, by choosing the medium, must use her hands. The individual finger grooves determine where a palm may easily fit; the uneven or relatively symmetrical form of a pot is created by the individual potter. Thus the potter becomes a part of the object. The human mind reaches out visually, but the human hand is always ready to reach out and investigate how an object "feels."

I became a clay artist the first time I discovered that the mud under our cedar trees would accept my clumsy attempts to make dishes for my mom. For years she cherished a set of dishes that had somehow found its way out of the North Carolina Mountains into her kitchen. My visual and tactile memories of that tableware prompted a desire to create that led to a lifelong exploration of creating from the earth.

With this body of work I continue a tradition in the design work on functional pottery. The bowl form is important in this exploration because of its symbolic connections to the feminine. Robin Hopper related in his book, Functional Pottery, that "vessels generally are the universal feminine symbol, the womb of 
the Great Mother, shelter, protection, preservation, nourishment and fertility, bowls represent giving or offering and fertility" (Hopper, 1986). My intent is to fortify the feminine with my vision of the feminine found in our Mother Earth; Hopper includes in his focus on the feminine "Lidded forms, covered jars, boxes, urns or bottles represent the feminine principle of containing, enclosure, or the womb" (Hopper, 1986). We have observed these forms as feminine throughout history in the sacred objects, jewels and the mementos which are held precious by their owners.

Mingei, or "folk ware," was given this title by the Japanese author of The Unknown Craftsman in 1926 to refer to common crafts that were pushed aside and unnoticed by the industrial revolution. Soetsu led a movement to acknowledge and embrace the philosophy of the handcrafter (Leach, 1972). Another early defender and master of pottery, Shoji Hamada, was an integral character in the folk craft movement. His aesthetic philosophies and technical expertise have influenced great numbers of functional potters worldwide. Hamada's humble functional ware provides the surface upon which he quickly and deliberately applied aesthetically pleasing decorations which are often abstract in their design.

Hamada established a workshop in Mashiko in 1923 upon his return from England where he had observed and experimented in the craft of English pottery with Bernard Leach in St. Ives. By 1955, he had become a "Living National Treasure" in Japan. Hamada, the master, often welcomed young artists and from his workshop continue to come many clay artists who have shared their experiences worldwide. Tom Marsh was one of those apprentices who returned to the US to share his knowledge and philosophy on the art craft movement in the East.

My background in pottery comes under the early tutelage of Tom Marsh. Tom 
was a master craftsman who concentrated in functional ware.

He was my hero.

Searching for a place, a niche, that feeds one's passion, is a lifelong search for some artists. Other creators know in their soul what they want to explore. A lucky few of us know our place and find the perfect master to assist in our exploration.

Beyond learning the technical aspects of a well thrown pot, I learned to embrace a philosophy at the wheel of Tom Marsh. His daily modeling routinely turned into life lessons when he would share where he came from, where he was, and where he wanted to be.

Through a series of personal and spiritual circumstances, Tom went to Japan to find his path. He spent time around a Buddhist Monastery where he desired to gain acceptance. Tom wanted to find that inner something that we all search for. Eventually Tom was accepted into the monastery. Within that first year he was loaned out to a local potter. Here is where my master met his master. Shoji Hamada was master of the Mashiko compound.

Tom lectured as he threw most days, and I eagerly went to my wheel afterwards to practice, to explore, and ultimately to become the potter that I am.

There would be days that I practiced the art of pulling handles. Tom made the concept click when he asked me if I had ever milked a cow. I had. Handles became as easy as milking a cow. The technical aspects of making a good pot came from sitting in my seat, throwing, and listening to Tom. He often spoke about the spiritual aspects of creating from the earth. And, just as often, we explored the technical aspects of a well thrown vessel.

Tom died in1991 and I came to study under a new master in 2002. Richard Burns 
offered a new view on clay and I hesitantly began to explore more unstructured but aesthetically pleasing bowls and vessels.

Although still throwing on the wheel, Todd ( Richard Burns) encouraged me to venture into unrestrained textural applications. He encouraged me to explore cutting and distorting and applying wads of half liquid slip then to scrape it off. I had crossed a line that I had drawn between function and "art." What I discovered is that there is no line.

Thinking about Mishima in a new way came as I explored applying and cutting or scraping away slip. Far from the precise practice of ancient Mishima, I have embraced this new-found, from the soul, transformation of the bowl. As in past modern art, I can abandon the basic construction of utilitarian ware, without leaving behind my past in clay.

While producing this body of work, I found the freedom to create a representation of what I have learned under two very technically superior clay artists, who are supremely different in their approach to the use of clay in art. 


\section{MY PROCESS}

Thinking and reading about Byzantine Art, I came to admire the Byzantine icons of Mary, Mother of Christ. The simple lines and flat design of the images inspired me to design a simple image of the Virgin and employ the process of Mishima. As the image and shape of "I Gave My Only Begotten Son" formed in my mind, so it did in the clay.

A large low bowl was thrown on the wheel. At the leather hard stage I traced through a drawing on tracing paper, leaving an indentation of the image on the face of the bowl. I carved the lines deeper using a simple carving tool, filled the furrows with white slip and allowed the piece to rest for about four hours.

The excess slip was initially scraped with a plastic rib then finished with a green "scrubbie." I found, through process, that finishing the removal of the excess slip with the common green scrubbie allowed my clay body to be smooth and pleasing to the touch.

A Bowl Is A Bowl is in extreme opposition to the Mary bowl. This piece was wheel-thrown and altered. The surface is bumpy, jagged and smooth. After throwing the taller bowl form, I hesitantly, and I'm sure with a wince, cut a hole in the well-formed bowl. After cutting through the piece, I hand applied very thick white slip. There was no intended scheme or justifiable reason to the application. The slip was thrown on the surface, rubbed, cut, combed, and dug out. Many of the clay pieces cut from the form remain with the body, just in a different form. While being free to "ruin" a perfectly good and, may I add, well-formed bowl, I had created a free but still controlled piece. I 
had created myself. 


\section{SUMMARY AND CONCLUSIONS}

In his book, Thinking Through Craft, Glenn Adamson refers to a refined 1970 Essay, "Some Notes on the Phenomenology of Making," by Robert Morris. Says Adamson, "Much attention has been focused on the analysis of the content of art making --its end images-- but there has been little attention focused on the significance of the means ... I believe there are 'forms' to be found within the activity of making as much as within the end products. These are forms of behavior aimed at testing the limits and possibilities involved in that particular interaction between one's actions and the materials of the environment" (Glenn, 2007). I remember a quote attributed to Michelangelo about the statue already existing within the stone; I found the same excitement in scraping and cutting away slip from a bowl to expose the inner aspects of the earth.

The newer forms I created are experiments in fluidity. Clay can be very rigid but that rigidity can be visually fluid. The folding allows the eye and hand to realize the movement of line in a rigid medium. The salt glaze finish allows the folded pieces to remain a part of the earth from whence they came.

These artifacts represent my exploration of clay. The initial thoughts of the bowl were of the feminine and they still are. I have learned that the initial quote of Ptah Ho-Tep, "There is nothing new under the sun" remains true. A bowl is a bowl. 


\section{REFERENCES}

Adamson, G. (2007). Thinking through craft. London, England: Berg.

Hopper, R. (1986). Functional pottery, form and aesthetic in pots of purpose. Radnor, PA: Chilton.

Jacq, C. (2004). The wisdom of ptah ho-tep: Spiritual treasures from the age of the pyramids. London, England: Constable and Robinson, Ltd.

Rawson, Phillip. (1971). Ceramics. London, England: Oxford university press.

Yanagi, S. (1972). The unknown craftsman. Adapted by Bernard Leach. New York: Kodansha international. 
APPENDIX

Body of Work

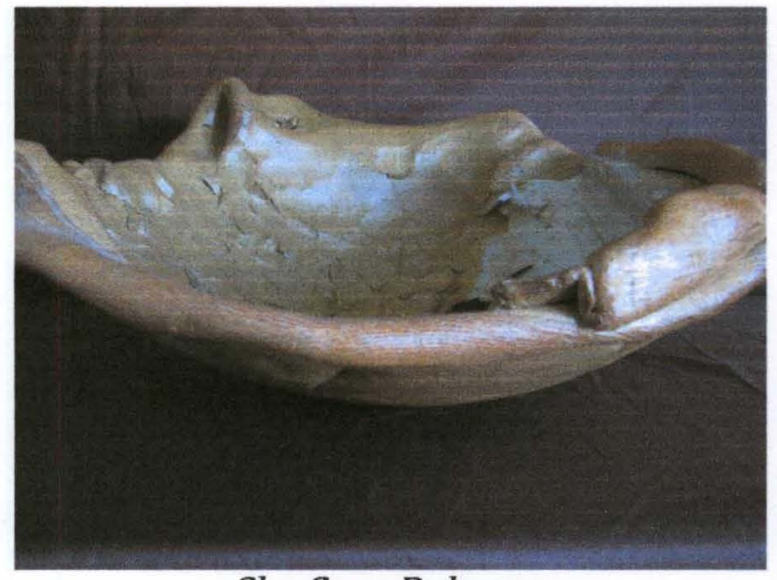

She Gave Balance

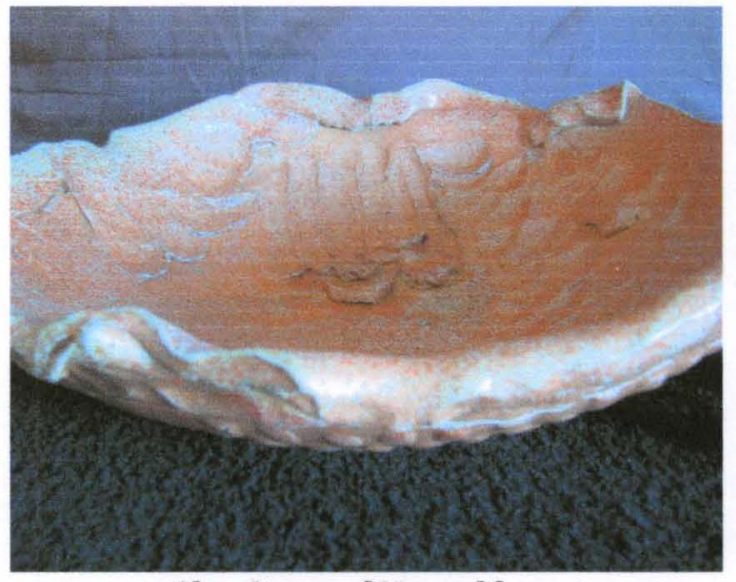

She Gave of Herself

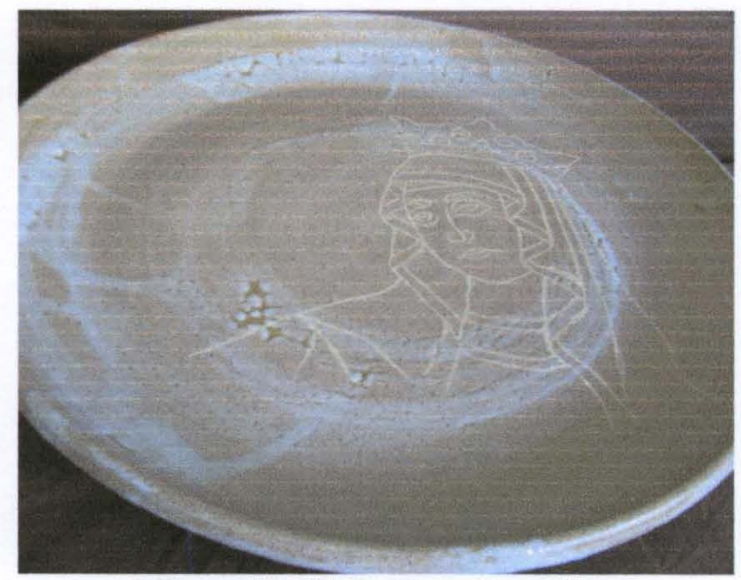

I Gave My Only Begotten Son

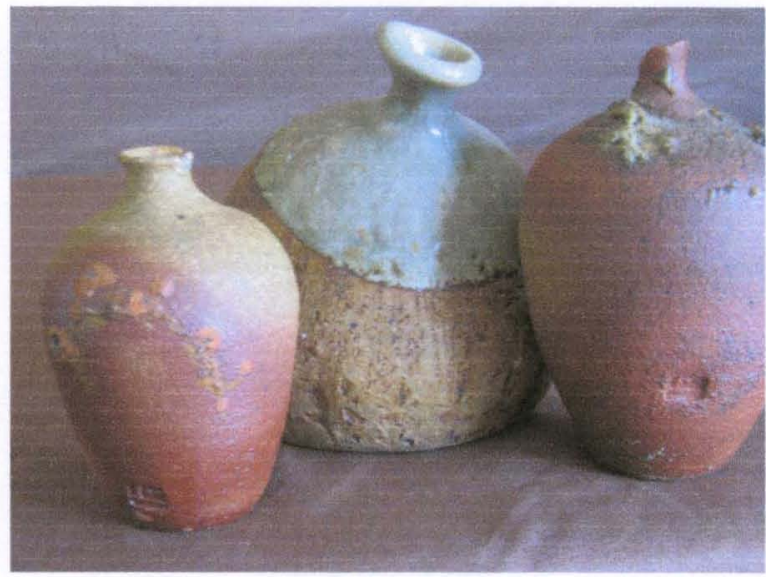

Oil Vessels 


\section{CURRICULUM VITAE}

Name: $\quad$ Sharon Gay Madison

Address: $\quad 535$ Arlington Drive

Elizabethtown, Kentucky 42701

DOB: $\quad$ Covington, Kentucky - January 18, 1955

Education and Training: A.S. Biology

University of Kentucky

1988

B. A. Ceramics

University of Louisville 1994

Master of Arts, Ceramics

University of Louisville

May, 2011

Professional Societies: Kentucky Crafted Market: 1995 - present

Work History: High School Arts \& Humanities Teacher: $2000-2011$

Owner: Rare Earth Pottery, Elizabethtown, Ky 1995-2000

Artist in Residence: Bullitt County Schools 1995-1998

Professional Memberships: Kentucky Crafted Market 1995- Present

Original artwork sold to consumers world-wide, every continent except Antarctica

Interests: $\quad$ Philosophy: Aesthetics, Nature, and Memory

Exploration of Art and Humanities through story 